\title{
Effect of the Roasting Conditions on the Secondary Metabolites, Phenolic Compounds and Antiradical Activity of Gabou
}

\author{
Maman Moustapha RABIOU ${ }^{1 *}$, Yaya Alain KOUDORO², Cokou Pascal AGABANGNAN DOSSA², \\ Haoua $\mathrm{SABO}^{1}$, Hassimi SADOU ${ }^{1}$, Dominique C.K. SOHOUNHLOUE ${ }^{2}$ \\ ${ }^{1}$ Laboratoire de Nutrition et de Valorisation des Agro ressources, Département de Chimie, Faculté des Sciences et \\ Techniques, Université Abdou Moumouni, BP 10662 Niamey, Niger. \\ ${ }^{2}$ Unité de réaction sur les Interactions Moléculaires (URIM), Laboratoire d'Etude et de Recherche en Chimie \\ Appliquées (LERCA); Ecole Polytechnique d'Abomey-Calavi, Université d'Abomey-Calavi. 01 BP 2009 Cotonou, \\ République du Bénin. \\ E-mail: Rabiouitina@gmail.com
}

\begin{abstract}
Gabou is a traditional seasoning derived of onion commonly used in Niger. It is obtained by roasting the different organs of Allium сера. The secondary metabolites, total phenolic content and antiradical activity of the different onion organs were determined and compared to those of their roasted products (Gabou). The results obtained showed the presence of flavonoids and reducing compounds in the samples analyzed. Depending on the type of Gabou, leucoanthocyanins, mucilages, saponosids, anthraquinons, sterols and terpens were detected or not detected. The levels of total phenols and total flavonoids ranged from 65.6 to $78.6 \mathrm{mg}$ EAG/100g and 61.1 to $65.2 \mathrm{mg}$ EQ/100g respectively. The antiradical activity ranged from 24.3 to $94.4 \mathrm{mg}$ EAA/100g. Roasting caused a significant increase $(\mathrm{p}<0.05)$ in antiradical activity and a no significant increase $(\mathrm{p}>0.05)$ in total flavonoid and phenol levels.
\end{abstract}

Keywords: Gabou, Allium cepa, traditional seasoning, roasting, metabolites, phenolic compounds, antiradical activity

\section{Introduction}

Allium cepa is a herbaceous monocotyledon belonging to the family of Amaryllidaceae [1]. It consists of a tray on which elongated, cylindrical, hollow green leaves and adventitious roots are inserted. The upright flower stems are also hollow. The leaf base can swell when conditions are favorable and form a bulb [2]. Allium cepa is an excellent source of nutrients. Indeed, this plant provides significant amounts of vitamins C, B6, potassium, bioactive components as well as calcium and of iron [3]. Among the bioactive compounds are phenolic compounds such as flavonoids (mainly quercetin), anthocyanins which are antioxidants [4].

In Niger, flower stems, green leaves and onion bulbs are transformed into a traditional seasoning called Gabou. Gabou is used in both rural and urban areas to season sauce. It is a low-energy charge seasoning, low in sodium and rich in calcium, iron and zinc [5]. In addition, the production of Gabou contributes to the reduction of crop losses. These losses are mainly due to the high seasonality of production and the lack of modern conservation infrastructure [6]. With a low moisture content of 2.49 to $14.75 \%$ [5], Gabou is easier to store than onion. Gabou production is a lucrative activity, mainly for women. Despite its advantages, Gabou production is now threatened by the presence of industrial seasonings [7]. The valorization of Gabou could not only allow this seasoning condiment to maintain its place in local markets but also to conquer other markets. It would also contribute to the development of the onion sector, which suffers from huge post-harvest losses. The valorization of Gabou requires as a prerequisite a better knowledge of its manufacturing process.

The roasting is considered as a very important stage of the production of Gabou due to the development of sensory quality. Roasting is a heat processing method that uses a dry heat treatment and causes a Maillard reaction [8]. Many published works have reported that the roasting not only affect changes in the physical characteristics and flavor, but also in the chemical composition of food [9-12]. Importantly, both temperature and time are considered the most important conditions of the roasting 
process. Thus, this study sought to investigate the effect of roasting temperature and time on the secondary metabolites, total phenolic content and antiradical activity of Gabou.

\section{Material and Methods}

\subsection{Reagents and Solvents}

The reagents and solvents used are 1,1-diphenyl-2-picryl-hydrazyl (DPPH), Folin-Ciocalteu reagent, Mayer reagent, Felhing reagent, Shinoda reagent, ascorbic acid, gallic acid, picric acid, hydrochloric acid $(\mathrm{HCl})$, aluminium trichloride $\left(\mathrm{AlCl}_{3}\right)$, ferric chloride $\left(\mathrm{FeCl}_{3}\right)$, sodium carbonate $\left(\mathrm{Na}_{2} \mathrm{CO}_{3}\right)$, sodium nitrite $\left(\mathrm{NaNO}_{2}\right)$, ammonia $\left(\mathrm{NH}_{3}\right)$, magnesium $(\mathrm{Mg})$, petroleum ether, quercetin and ethanol. All reagents and solvents used come from Sigma.

\subsection{Plant Material}

The plant material consists of floral stems, green leaves and bulbs of Allium cepa supplied in the commune of Sakoira (Niger) located between latitudes $1^{\circ} 24^{\prime} 0^{\prime \prime} \mathrm{E}$ and longitudes $14^{\circ} 16^{\prime} 60^{\prime \prime} \mathrm{N}$. The variety of onion used is called 'Gothèye white'. Its bulb of strong and pungent flavor is white, spherical in shape with several lobes such as shallot or even garlic. Its elongated green leaves and upright flower stems are cylindrical and hollow. The roasting products called Gabou in the local language (Djerma) in Niger were developed in the laboratory and stored in hermetically sealed jars until analysis.

\subsection{Preparation of the Plant Material}

Flower stems, green leaves and bulbs of Allium cepa were used to produce Flower Stem Gabou (FSG), Green Leaf Gabou (GLG) and Onion Bulb Gabou (OBG) respectively. The roasting was carried out in an electric oven. The fabrication processes of these Gabou are summarized below [7].

Flower Stem Gabou (FSG): the onion flower stems were carefully washed, cut into 2 to $3 \mathrm{~cm}$ long pieces and dried at $50^{\circ} \mathrm{C}$ in an oven. The dried stem pieces obtained were roasted at $130^{\circ} \mathrm{C}$ for 11 minutes.

Green Leaf Gabou (GLG): the onion green leaves were carefully washed, slightly crushed in a mortar and dried at $50^{\circ} \mathrm{C}$ in an oven. $30 \mathrm{~g}$ of dried leaf mash were roasted at $120^{\circ} \mathrm{C}$ for 5 min after adding $2 \mathrm{ml}$ of palm oil and homogenizing.

Onion Bulb Gabou (OBG): the onion bulbs were peeled, washed, cut and dried at $50^{\circ} \mathrm{C}$ in an oven. The small pieces of bulbs obtained were roasted at $120^{\circ} \mathrm{C}$ for 8 min by adding and mixing beforehand 1 $\mathrm{ml}$ of palm oil per $30 \mathrm{~g}$.

\subsection{Identification of Metabolites}

All samples were reduced to fine powder using a 300um mesh mill. The detection of metabolites was carried out by coloring and precipitation reactions specific to each metabolite family [13 - 15]. The secondary metabolites sought are flavonoids, anthocyanins, tannins, alkaloids, leucoanthocyans, mucilages, reducing compounds, saponosides, anthraquinones, coumarins, cyanogenic and sterol compounds and terpenes.

\subsection{Extraction of Phenolic Compounds}

$5 \mathrm{~g}$ of each sample was macerated in $50 \mathrm{ml}$ of solvent (ethanol/water: $7 / 3$ ) at laboratory temperature for 24 hours. The macerate was filtered on whatman paper $\mathrm{n}^{\circ} 1$. The filtrate obtained was stored in a refrigerator for analysis.

\subsection{Determination of Total Phenol Content}

The total phenol content of the extracts was determined by the Folin-Ciocalteu method, which was modified in our laboratory [16]. $3 \mathrm{ml}$ of distilled water was added to $50 \mu \mathrm{l}$ of extract and then $250 \mu \mathrm{l}$ of 
Folin-Ciocalteu reagent and $750 \mu \mathrm{l}$ of $7 \%$ sodium carbonate solution. After $8 \mathrm{~min}, 950 \mu \mathrm{l}$ of distilled water was added and the mixture was incubated at room temperature for 2 hours. The reading was made using a spectrophotometer at $765 \mathrm{~nm}$ against a white. The total phenol content was determined by the calibration curve performed with gallic acid at different concentrations under the same conditions as the sample. The results were expressed in milligrams of gallic acid equivalent per $100 \mathrm{~g}$ of sample.

\subsection{Determination of Total Flavonoid Content}

The flavonoid content of extracts was determined using a modified colorimetric method [17]. To $100 \mathrm{ml}$ of extract, add $0.4 \mathrm{ml}$ of distilled water and then $0.03 \mathrm{ml}$ of $5 \%$ sodium nitrite solution. After $5 \mathrm{~min}, 0.02$ $\mathrm{ml}$ of $10 \%$ aluminum chloride solution was added. $0.2 \mathrm{ml}$ of $1 \mathrm{M}$ sodium carbonate solution and $0.25 \mathrm{ml}$ distilled water was added to the mixture after 5 minutes of rest. The whole thing was vortexed. Absorbance was measured at $510 \mathrm{~nm}$. The results were expressed in milligrams of quercetin equivalent per $100 \mathrm{~g}$ of sample.

\subsection{Evaluation of Antiradical Activity}

Antiradical activity was evaluated using the DPPH (2, 2-diphenylpicrylhydrazyle) free radical scavenging method. Briefly, $200 \mu \mathrm{l}$ of diluted extract five (5) times of sample were mixed with $3800 \mu \mathrm{l}$ of $100 \mu \mathrm{M}$ DPPH solution. The mixture was placed in the dark for 2 hours. Absorbance was measured at $517 \mathrm{~nm}$ using a spectrophotometer. The percentage of inhibition of DPPH radicals was calculated according to the equation:

$$
\% \text { of inhibition }=\left(\left(\text { Abs Blank }_{-} \text {Abs Sample }\right) / \text { Abs Blank }\right) \times 100
$$

Ascorbic acid was used as a standard reference to convert the percentage of inhibition of each sample into equivalent antiradical activity of ascorbic acid. Antiradical activity was determined by the calibration curve performed with ascorbic acid at different concentrations under the same conditions as the sample. The results were expressed in milligrams of ascorbic acid equivalent per $100 \mathrm{~g}$ of sample [16, 18]. All values were presented as the mean \pm standard deviation of at least three repetitions.

\subsection{Statistical Analysis}

The statistical analysis was performed using Minitab version 16. The results were subjected to analysis of variance, and differences between the means were determined using the Tukey multiple comparison test. The difference is significant at $\mathrm{p}<0.05$.

\section{Results and Discussion}

\subsection{Metabolites of the Different Organs of Allium Cepa and Gabou}

Secondary metabolites identified in flower stems, green leaves, onion bulbs and Gabou were presented in Table 1. Analysis of these results showed that flavonoids and reducing compounds were present in all samples studied, whereas anthocyanins, tannins, alkaloids, coumarins and cyanogenic compounds were not detected. The absence of these compounds could be favorable to the sapidity of Gabou. Indeed, most of the undetected compounds are bitter and/or astringent [19]. At high concentrations, these compounds can alter taste and even become toxic [20]. In addition, some of these compounds, such as tannins and cyanogenic compounds, are anti-nutritional factors. Leucoanthocyanins were present in all samples except for the green leaves and their Gabou. Anthraquinones were not detected at the levels of green leaves, onion bulbs and their Gabou but were detected in the other samples. Among the samples studied, tests to identify mucilages, sterols and terpenes do not revealed the presence of these metabolites in onion bulbs and its Gabou. Mucilages were also absent in the green leaves Gabou. Saponosides were present in flower stems, green leaves and their Gabou. The results of the phytochemical screening of the onion bulb reported in this study were in agreement with those of previous work [21, 22]. However, these authors detected the presence of tannins and alkaloids respectively, which were not identified at the 
level of onion bulbs of the 'Gothèye white' variety studied. In addition, sterols and terpenes absent in onion bulbs were identified by several authors [23-25]. The difference in the distribution of secondary metabolites observed in the onion bulb may be related to production, storage, varietal difference or climatic factors $[21,26,27]$. It is important to note that all the compounds found in floral stems, green leaves and onion bulbs were also found in their roasted products (Gabou). Except for the mucilages that were not detected in the flower stems Gabou. This means that the roasting temperature and time chosen to roast the flower stems, green leaves and onion bulbs did not completely alter the chemical functions of the metabolites identified.

Table 1. Metabolites of the various organs of Allium cepa and Gabou

\begin{tabular}{|c|c|c|c|c|c|c|}
\hline Metabolites & $\begin{array}{l}\text { Floral } \\
\text { Stems }\end{array}$ & $\begin{array}{c}\text { Floral Stems } \\
\text { Gabou }\end{array}$ & $\begin{array}{l}\text { Green } \\
\text { Leaves }\end{array}$ & $\begin{array}{c}\text { Green Leaves } \\
\text { Gabou }\end{array}$ & $\begin{array}{l}\text { Onion } \\
\text { bulbs }\end{array}$ & $\begin{array}{c}\text { Onion bulbs } \\
\text { Gabou }\end{array}$ \\
\hline Flavonoïds & + & + & + & + & + & + \\
\hline Anthocyans & - & - & - & - & - & - \\
\hline Tannins & - & - & - & - & - & - \\
\hline Alcaloïds & - & - & - & - & - & - \\
\hline Leucoanthocyans & + & + & - & - & + & + \\
\hline Mucilages & + & - & + & + & - & - \\
\hline Reducing compound & + & + & + & + & + & + \\
\hline Saponosids & + & + & + & + & - & - \\
\hline Anthraquinons & + & + & - & - & - & - \\
\hline Coumarins & - & - & - & - & - & - \\
\hline Cyanogenic compound & - & - & - & - & - & - \\
\hline Sterols and terpens & + & + & + & + & - & - \\
\hline
\end{tabular}

Legends: - Absence and + presence.

\subsection{Total Phenol and Flavonoid Content of the Different Organs of Allium Cepa and Gabou}

Epidemiological studies have indicated that fruit and vegetable consumption is associated with a reduced risk of developing chronic diseases, such as cardiovascular disease and cancer [28]. Phytochemical compounds, including phenols and flavonoids, are considered to be the main bioactive compounds that contribute to the health benefits of fruits and vegetables [29, 30]. The total phenol contents expressed in milligrams of gallic acid equivalent per 100 grams of sample (mg EAG/100 g sample) were presented in Table 2. Analysis of these results showed that there are no significant differences in total phenol levels between the samples studied. These levels ranged from 71.10 to 78.66 mg EAG/100g of sample. The Gabou of floral stems was the richest in total phenols whereas the onion bulb was the least rich in total phenols. After roasting, Table 2 showed an insignificant increase $(\mathrm{p}>0.05)$ in total phenol levels in all Gabou. In the literature, a significant increase in total phenol levels was reported by Thidarat et al. [31]. The increase in total phenol levels could be due to the cleavage of bound phenolic compounds or the formation of Maillard reaction products (MRP) during roasting. Indeed, PRMs have a phenolic structure and the Folin Ciocalteu reagent is a non-specific reagent, extremely sensitive to the reduction of all hydroxide groups. Thus, the reagent reduces not only the hydroxide groups of phenolic compounds but also of some Maillard reaction products [32, 33]. The total phenol content of the onion bulb of the 'Gothèye white' variety studied ( $0.71 \mathrm{mg}$ EAG/g sample) does not belong to the ranges of total phenol contents reported in previous studies [18, 34, 35]. The values reported by these authors ranged from 2.5 to $7.83 \mathrm{mg}$ EAG/g. The difference observed could be related to the varietal difference, production and storage conditions $[18,36]$ but also to the sample preparation and extraction conditions followed during the experiment [37]. Table 2 also presented the total flavonoid contents expressed in milligram equivalent quercetin per 100 gram of sample (mg Eq/100g). At this level too, there is no significant difference in total flavonoid levels between the samples studied. These levels ranged from 51.42 to $65.20 \mathrm{mg} \mathrm{Eq} / 100 \mathrm{~g}$ of sample. Table 2 showed that roasting had little influence on flavonoid levels. However, an upward trend was observed. During the soja roasting process, Thidarat et al. [31] reported an increase in flavonoid content. The increase in flavonoid content in 
Gabou may result from the cleavage of quercetin heterosides (flavonoids) into sugars and aglycone (quercetin) or from the reaction products of the Maillard formed during roasting.

Table 2. Levels of total phenols and flavonoids expressed in $\mathrm{mg} / 100 \mathrm{~g}$ of the various organs of Allium cepa and Gabou

\begin{tabular}{lcc}
\hline Products & Total Phenols $(\mathrm{mg}$ EAG $/ 100 \mathrm{~g})$ & Total Flavonoids $(\mathrm{mg}$ EQ/100g) \\
\hline Floral Stems & $73.81 \pm 1.67^{\mathrm{a}}$ & $51.42 \pm 5.24^{\mathrm{a}}$ \\
Floral Stems Gabou & $78.66 \pm 1.88^{\mathrm{a}}$ & $65.20 \pm 4.34^{\mathrm{a}}$ \\
Green Leaves & $72.32 \pm 2.08^{\mathrm{a}}$ & $52.59 \pm 12.04^{\mathrm{a}}$ \\
Green Leaves Gabou & $72.51 \pm 2.10^{\mathrm{a}}$ & $64.99 \pm 1.94^{\mathrm{a}}$ \\
Onion Bulbs & $71.10 \pm 2.11^{\mathrm{a}}$ & $53.65 \pm 13.49^{\mathrm{a}}$ \\
Onion Bulbs Gabou & $72.26 \pm 2.13^{\mathrm{a}}$ & $61.14 \pm 2.5^{\mathrm{a}}$ \\
\hline
\end{tabular}

There is no significant difference $(\mathrm{p}>0.05)$ between the averages that have the same letter in each column.

\subsection{Antiradical Activity of the Different Organs of Allium Cepa and Gabou}

Antiradical activity characterizes the ability of components to react with free radicals [38]. Figure 1 showed the percentage of inhibitions of flower stems, green leaves and onion bulbs and their Gabou. The results showed that all the sample extracts studied had the ability to trap the stable radical $\mathrm{DPPH}^{\bullet}$. For a concentration of $0.01 \mathrm{~g} / \mathrm{ml}$ of extracts, the percentages of inhibitions varied from 9.66 to $93.00 \%$. The highest percentage obtained in the Gabou of floral stems was close to $98.44 \%$ of ascorbic acid, the reference antioxidant. The percentages of inhibitions obtained were converted into equivalent antiradical activity ascorbic acid. The results were expressed in $\mathrm{mg}$ ascorbic acid equivalent per 100 grams of sample (mg EAA/100g). Figure 2 showed that the antiradical activity varied from 9.99 to $94.48 \mathrm{mg}$ EAA /100g. Among the different organs of Allium cepa, there was a significant difference $(\mathrm{p}<0.05)$ in antiradical activity. Thus, flower stems had the highest antiradical activity (33.87 \pm 1.9$)$ followed by green leaves $(17.42 \pm 0.3)$ and bulbs $(9.99 \pm 3.1)$. A significant difference was also found between the different Gabou. Thus, the Gabou of flower stems had the highest antiradical activity (94.48 \pm 3.3 ) followed by the Gabou of green leaves $(29.01 \pm 4.2)$ and the Gabou of onion bulbs $(24.30 \pm 5.7)$. Concerning the effect of roasting, figure 2 showed that it has caused a significant increase $(\mathrm{p}<0.05)$ in antiradical activity in all Gabou. Similar observations were reported by several authors [31, 39, 40]. Indeed, the antiradical activity can increase or decrease depending on the roasting temperature and time combination and the chemical composition of the roasted material. Thus, the roasting of starch-rich materials would be accompanied by an increase in antiradical activity. Antiradical activity would also increase during medium roasting [39]. The variation in antiradical activity is the result of the thermal degradation of natural antioxidants and the formation of Maillard reaction products that have antiradical activity [41].

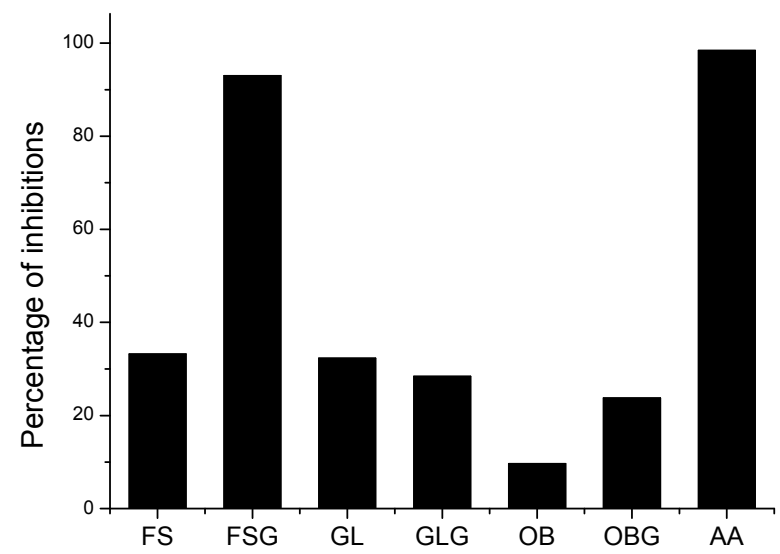

Figure 1. Percentage of inhibitions of Floral Stems (FS), Floral Stems Gabou (FSG), Green Leaves (GL), Green leaves Gabou (GLG), Onion Bulbs (OB), Onion Bulbs Gabou (OBG) and ascorbic acid (AA). 


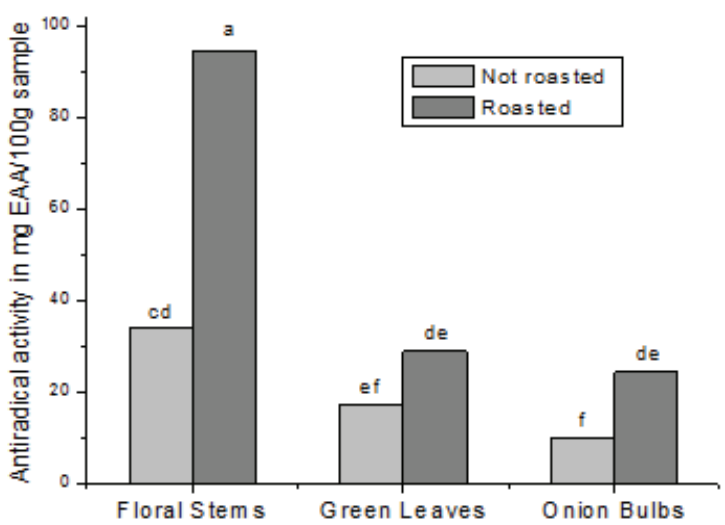

Figure 2. Antiradical activity of the different organs of Allium cepa and Gabou. The averages that do not have the same letters in each column are significantly different $(\mathrm{p}<0.05)$.

\section{Conclusion}

This study contributes to the exploration of the chemical potential and antiradical activity of the different organs of Allium cepa and Gabou. It also provided information on the effect of the roasting temperature and time chosen to produce the three types of Gabou. Through the results obtained, the different organs of Allium cepa and their Gabou contain secondary metabolites such as reducing compounds and flavonoids. The most interesting antiradical activity is obtained at the level of floral stems Gabou. The roasting temperature and time did not significantly improve the total phenol and total flavonoid contents. However, a significant improvement in antiradical activity was recorded. In perspective, it is important to determine the profile of the volatile compounds generated during the production of Gabou.

Acknowledgements. The authors would like to thank Professor Dominique C.K. Sohounhloué for hosting the Laboratoire d'Etude et de Recherche en Chimie Appliquée, Ecole Polytechnique d'AbomeyCalavi, Université d'Abomey-Calavi (LERCA/EPAC/UAC).

Conflict of Interest. The authors state that there is no conflict of interest.

\section{References}

1. R. M. Fritsch and N. Friesen, "Evolution, domestication and taxonomy", in Allium crop science: recent advances. Wallingford, UK; New York, USA: CABI Publishing. 2002, pp. 5-30.

2. C. Foury and B. Schweisguth, "L'oignon", in Amélioration des espèces végétales cultivées. Paris: INRA. 1992, pp. 406-419.

3. C. Reed, "Import Risk Analysis: Onions (Allium cepa Liliaceae) Fresh Bulbs for Consumption from China", 2009. http://www.biosecurity.govt.nz/files/biosec/consult/draft-ira-onions-from-china.pdf.

4. M. Rhodes and K. Price, "Analytical problems in the study of flavonoid compounds in onions", Food Chemistry, vol. 57, no. 1, pp. 113-117, 1996.

5. M. M. Rabiou, C. Yaou, M. Lewamy and H. Sadou, "Evolution of the Chemical Composition during the Fabrication of the Different Types of Gabou, a Traditional Onion-Based Spice Commonly Used in Niger", Journal of Food Processing \& Technology, vol. 9, no. 8, 2018a. Doi: 10.4172/2157-7110.1000748.

6. M. M. Rabiou, I. Moussa, T. Mella and H. Sadou, « Panorama of Onion Production in Tillabéri, A Region of the Far West of Niger", European Scientific Journal, vol. 14, no. 15, 2018b. http://dx.doi.org/10.19044/ esj.2018.v14n15p175.

7. M. M. Rabiou, C. Yaou, M. Lewamy, I. Moussa, H. Sabo and H. Sadou, "Determination of Optimal Roasting Conditions for the Production of Gabou", Journal of Food Research, (submitted). 
8. T. Oliviero, E. Capuano, B. Cammerer and V. Fogliano, "Influence of roasting on the anti-oxidant activity and HMF formation of a cocoa bean model systems", Journal of Agricultural and Food Chemistry, vol. 57, no. 1, pp. 147-152, 2009.

9. K. S. Youn and H. S. Chung, "Optimization of the roasting temperature and time for preparation of coffee-like maize beverage using the response surface methodology", LWT Food Science and Technology, vol. 46, pp. 305$310,2012$.

10. M. Fikry, Y. A. Yusof, A. M. Al-Awaadh, R. A. Rahman, N.L. Chin, E. Mousa and L. S. Chang, "Effect of the Roasting Conditions on the Physicochemical, Quality and Sensory Attributes of Coffee-Like Powder and Brew from Defatted Palm Date Seeds", Foods, vol 8, nº61, 2019. Doi: 10.3390/foods8020061

11. S. Bolek and M. Ozdemir, "Optimization of roasting conditions of Pistacia terebinthus in a fluidized bed roaster", LWT Food Science and Technology, vol. 80, pp. 67-75, 2017.

12. G.C. Yen, and D.Y. Chung, "Antioxidant effects of extracts from Cassia tora L. pre-pared under different degrees of roasting on the oxidative damage to biomolecules", Journal of Agricultural and Food Chemistry, vol. 47, no. 4, pp. 1326-1332, 1999.

13. G. E. Trease and W. C. Evans, "Pharmacognosy", 13th ed. Bailliere Tindall, London. 1989.

14. R. Dohou, K. Yamni, S. Tahrouch, L. I. Hassani, A. Badoc and N. Gmira, "Screening phytochimique d'une endémique iberomarocaine, Thymelaea lythroides", Bulletin-Société de Pharmacie de Bordeaux, vol. 142, pp. 61$78,2003$.

15. A. Y. Koudoro, A. D. C. Pascal, Y. Boniface, T. F. Paul, A. G. Alain, A. Felicien,... \& S. K. C. Dominique "Chemical characterization and biological activities of extracts from two plants (Cissus quadrangularis and Acacia polyacantha) used in veterinary medicine in Benin", Journal of Pharmacognosy and Phytochemistry, vol.3, no. 6, pp. 91-96, 2015.

16. D. C. P. Agbangnan, J. P. Noudogbessi, A. Chrostowska, C. Tachon, E. Fouquet and D. C. K. Sohounhloue, "Phenolic compound of Benin's red sorghum and their antioxidant properties", Asian Journal of Pharmaceutical and Clinical Research, vol. 6, no. 2, pp. 277-280, 2013.

17. J. Zhishen, T. Mengcheng and W. Jianming, "The determination of flavonoid contents in mulberry and their scavenging effects on superoxide radicals", Food chemistry, vol. 64, no 4, pp. 555-559, 1999.

18. J. Yang, K. J. Meyers, J. van der Heide and R. H. Liu, "Varietal differences in phenolic content and antioxidant and antiproliferative activities of onions", Journal of agricultural and food chemistry, vol. 52, no. 22, pp. 67876793, 2004.

19. V. S. P. Chaturvedula and I. Prakash, "The aroma, taste, color and bioactive constituents of tea", Journal of Medicinal Plants Research, vol. 5, no. 11, pp. 2110-2124, 2011.

20. N. I. Bondjengo, G. Kitengie, D. Musibono, C. Lubini, G. Hohmann and B. Fruth, "Recherche d'alcaloïdes et hétérosides cyanogénétiques (cyanures) dans les fruits consommés par Pan paniscus à Luikotale dans le Parc National de la Salonga-Sud, RD Congo", Revue de primatologie, no. 5, 2013.

21. A. Ibrahim, "The Phytochemicals of Onion as Affected by Inorganic Fertilizer", International journal of biological sciences, vol. 01, no. 05, pp. 30-40, 2014.

22. M. D. D. Mangambu, K. F. Mushagalusa and N. J. Kadima, "Contribution à l'étude photochimique de quelques plantes médicinales antidiabétiques de la ville de Bukavu et ses environs (Sud-Kivu, RD Congo)", Journal of Applied Biosciences, vol. 75, no. 1, pp. 6211-6220, 2014.

23. S. Boukeria, K. Kadi, R. Kalleb, A. Benbott, D. Bendjedou and A. Yahia, "Phytochemical and physicochemical characterization of Allium sativum L. and Allium cepa L. Essential oils", Journal of Materials and Environmental Science, vol. 7, no. 7, pp. 2362-2368, 2016.

24. U. M. Sani and Y. Yakubu, "Phytochemical Screening and Anti-diabetic Potential of Ethanol Extracts of Cooked Allium cepa L. (onion)", The Pharmaceutical and Chemical Journal, vol. 3, no. 4, pp. 61-67, 2016.

25. T. S. Karande, N. Pawar, T. Katkar, M. Karanjkar, P. Bhushan and S. Khade, "Isolation and antimicrobial activity evaluation of some herbal extract", World Journal of Pharmacy and Pharmaceutical Sciences, vol. 7, no. 6, pp. 726-733, 2018.

26. A. Bilyk, P. L. Cooper and G. M. Sapers, "Varietal differences in distribution of quercetin and kaempferol in onion (Allium cepa L.) tissue", Journal of Agricultural and Food Chemistry, vol. 32, no. 2, pp. 274-276, 1984

27. B. S. Patil, L. M. Pike and B. K. Hamilton, "Changes in quercetin concentration in onion (Allium cepa L.) owing to location, growth stage and soil type", New phytologist, vol. 130, no. 3, pp. 349-355, 1995a.

28. G. Block, B. Patterson, and A. Subar, "Fruit, vegetables, and cancer prevention: a review of the epidemiological evidence", Nutrition and cancer, vol. 18, no. 1, pp. 1-29, 1992.

29. G. Bartosz, "Oxidative stress in plants", Acta Physiologiae Plantarum, vol. 19, no. 1, pp. 47-64. 
30. M. Leja, A. Mareczek and J. Ben, "Antioxidant properties of two apple cultivars during long-term storage", Food Chemistry, vol. 80, no. 3, pp. 303-307, 2003.

31. S. Thidarat, M. Udomsak, W. Jindawan, D. Namphung, Y. Suneerat, T. Sawan and T. Pisamai, "Effect of roasting on phytochemical properties of Thai soybeans", International Food Research Journal, vol. 23, no. 2, 2016.

32. S. Vuorela, "Analysis, isolation, and bioactivities of rapeseed phenolics (dissertation)", EKT series 1343. University of Helsinki. Department of Applied Chemistry and Microbiology. Food Chemistry. Helsinki, 75. 2005.

33. A. M. Gómez-Caravaca, M. Gómez-Romero, D. Arráez-Román, A. Segura-Carretero and A. FernándezGutiérrez, "Advances in the analysis of phenolic compounds in products derived from bees". Journal of Pharmaceutical and Biomedical Analysis, vol. 41, no. 4, pp. 1220-1234, 2006.

34. M. P. Kähkönen, A. I. Hopia, H. J. Vuorela, J. P. Rauha, K. Pihlaja, T. S. Kujala and M. Heinonen, "Antioxidant activity of plant extracts containing phenolic compounds", Journal of agricultural and food chemistry, vol. 47, no. 10, pp. 3954-3962, 1999.

35. S. Sellappan and C. C. Akoh, "Flavonoids and antioxidant capacity of Georgia-grown Vidalia onions", Journal of Agricultural and Food Chemistry, vol. 50, no. 19, pp. 5338-5342, 2002.

36. A. S. Rodrigues, M. R. Pérez-Gregorio, M. S. García-Falcón, J. Simal-Gándara and D. P. F. Almeida, "Effect of meteorological conditions on antioxidant flavonoids in Portuguese cultivars of white and red onions", Food Chemistry, vol. 124, no. 1, pp. 303-308, 2011.

37. J. Santas, R. Carbo, M. H. Gordon, and M. P. Almajano, "Comparison of the antioxidant activity of two Spanish onion varieties", Food Chemistry, vol. 107, no. 3, pp. 1210-1216, 2008.

38. E. B. Burlakova, A. V. Alesenko, E. M. Molochkina, N. P. Palmina and N. G. Khrapova, "Bioantioxidants in radiation damages and malignant growth". Moscow: Nauka (in Russian). 1975

39. G. Durmaz and M. Alpaslan, "Antioxidant properties of roasted apricot (Prunus armeniaca L.) kernel", Food Chemistry, vol. 100, no. 3, pp. 1177-1181, 2007.

40. Ö. Ç. Açar, V. Gökmen, N. Pellegrini and V. Fogliano, "Direct evaluation of the total antioxidant capacity of raw and roasted pulses, nuts and seeds", European Food Research and Technology, vol. 229, no. 6, pp. 961-969, 2009.

41. F. Hayase, S. Hirashima, G. Okamoto and H. Kato, "Scavenging of Active Oxygens by Melanoidins", Agricultural Biological Chemistry, vol. 54, no. 6, pp. 855-862, 1990. 